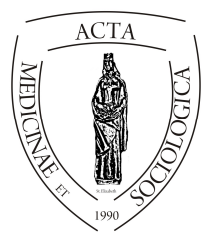

\title{
Serdülőkorúak egészségmagatartása a negatív életese- mények, a társas támogatottság, valamint a protektív és kockázati magatartások vonatkozásában
}

\author{
Ember Zsolt
}

egészségügyi szociális munkás, szociálpedagógus

\begin{tabular}{|c|c|}
\hline INFO & ABSTRACT \\
\hline $\begin{array}{l}\text { Zsolt Ember } \\
\text { zsolt.ember07@gmail.com }\end{array}$ & \multirow[b]{2}{*}{$\begin{array}{l}\text { Health Behavior of Adolescents in Negative Life Events, } \\
\text { Social Support, and Protective and Risk Behavior. The } \\
\text { examination of the health-behaviour of adolescents is in the } \\
\text { focus of the scientific research for long years. This is important, } \\
\text { because over the world - also in Hungary - it goes on the } \\
\text { continous and uninterruptedly growing decay of health- } \\
\text { behaviour of teen-ages for long. Smoking, alcohol- and drug- } \\
\text { consumption, the inadequate sexual attitudes are more and } \\
\text { more spreading among teenagers. Moreover these risks of } \\
\text { health-behaviour appears more and more in younger ages. It } \\
\text { could be placed many factors between reasons, such as defects } \\
\text { of socialization scenes, negative life-experiences and the social } \\
\text { effects, that are especially important in adolescence. We also } \\
\text { have to mention the negative cultural effects of the postmodern } \\
\text { era, for example diminish of classic, essential human and social } \\
\text { values, and the shallowness of friendly and parental } \\
\text { connections. In this paper I study health-behaviour of teen-age } \\
\text { youth with different socioeconomic background, analyzed with } \\
\text { half-structural interviews. In line with this the paper I enter into } \\
\text { details of negative life events of youth, and also discuss the } \\
\text { connections and impress on each other of these. }\end{array}$} \\
\hline $\begin{array}{l}\text { Keywords } \\
\text { adolescence, } \\
\text { school-aged children, } \\
\text { risk behaviour, } \\
\text { negative life events }\end{array}$ & \\
\hline $\begin{array}{l}\text { Kulcsszavak } \\
\text { serdülökor, } \\
\text { iskoláskorúak, } \\
\text { rizikómagatartás, } \\
\text { negatív életesemények }\end{array}$ & $\begin{array}{l}\text { Absztrakt: A serdülők egészségmagatartásának vizsgálata } \\
\text { hosszú évek óta a tudományos kutatások fókuszában áll. Ez } \\
\text { azért fontos, mert világszerte - nem kevésbé Magyarországon } \\
\text { - hosszú ideje tart a serdülőkorúak egészségmagatartásának } \\
\text { folyamatos és egyre nagyobb mértékü romlása. A dohányzás, } \\
\text { az alkoholfogyasztás, a droghasználat, az inadekvát szexuális } \\
\text { attitüdök mindinkább elterjedőben vannak a tizenévesek kö- } \\
\text { rében, ráadásul ezek az egészségmagatartási kockázatok } \\
\text { egyre fiatalabb korban jelentkeznek. Az okok közé számos } \\
\text { tényezőt sorolhatunk, úgymint a szocializációs színterek hiá- }\end{array}$ \\
\hline
\end{tabular}


tusait, a negatív élettapasztalatokat és a serdülőkorban oly jelentős társas hatásokat, de ugyancsak meg kell említenünk a posztmodern kor negatív kulturális hatásait is, mint pl. a klasszikus, alapvető emberi és társadalmi értékek háttérbe szorulását, a baráti és szülői kapcsolatok felszínessé válását, kiüresedését. A tanulmányban eltérő szocio-ökonómiai státusszal rendelkező serdülőkorú fiatalok egészségmagatartását vizsgálom félig strukturált interjúk elemzésével. Ennek kapcsán az írás kitér a fiatalokat ért negatív életesemények, valamint ezek összefüggéseinek és egymásra gyakorolt hatásainak taglalására is.

\section{Bevezetés}

A serdülőkor testi-lelki változásokkal terhelt időszak, mely az ifjúkori átmenet meghosszabbodása következtében vált kitüntetett életszakasszá a modern társadalomban (Pikó 2010d). A gyermek-felnőtt lét küszöbén álló fiatalok a maguk identifikációs és szociális nehézségeivel, az újonnan megkövetelt társadalmi szerepek adaptálása közben gyakran maradnak magukra, vagy tévednek el korunk információs dzsungelében. Az egyre elégtelenebbül funkcionáló szocializációs színterek már nem biztosítanak számukra biztos fogódzót, a folyton rohanó, önmagukkal sem törődő felnőttek pedig már nem partnerek az egészségnevelésben, egészségfejlesztésben. Pedig „ezen a bonyolult bio-pszicho-szociális változásrendszeren ,átkelve” a serdülö feladata, hogy optimális önértékelést alakitson ki, stabil (felnött) identitást hozzon létre, és megtalálja az önálló élethez szükséges szerepeket, kialakitsa az azokat felépitő viselkedésrepertoárt." (Költő és Zsiros 2013:187) Ez igen nehéz feladat, hiszen a modernizáció társadalom-lélektani fordulatot is eredményezett: az értékek pluralizálódása nemcsak előnyöket, hanem nehézségeket is okozott és nőtt a fenyegetések száma is. Az énközpontúság előtérbe kerülésével az egyének közötti viszonyok fellazultak, a felgyorsult életritmus okozta stressz pedig számos betegségnek lett táptalaja (Pikó 2010a).

A fiatalok a viharzás időszakában, ,új önmaguk” keresésében hajlamosak egészségkárosító viselkedésformákban keresni identitásukat, mint pl. a dohányzás, a drogés alkoholfogyasztás, valamint a felelötlen szexuális élet (Költő és Zsiros 2013). Teszik mindezt legtöbbször a kortárscsoportok hatására, melyeknek - még jól müködő szülö-gyermek közti kapcsolat esetén is - erős befolyásoló hatása van (Hüse, Huszti és Takács 2016). A serdülőnek ugyanis szüksége van a valahová való tartozás élményére. Számára a csoport modell és referenciakeret fóleg az életmód, az énkép, az önértékelés és a társas élet területén (Margitics 2009). A csoportnyomás azonban, mint viselkedési nyomás fontos kortárshatás, mely erős szerfogyasztási prediktor is egyben (Pikó 2010c). A dolgozat célja, hogy - a vizsgált kérdésekkel kapcsolatban egy ebben a témában viszonylag ritkán használt kutatási módszerrel, interjúk segítségével adjon képet serdülőkorúak magatartásáról. A dolgozat relevanciáját adja, hogy a serdülők egészségmagatartása egyre romló tendenciát mutat, melyet kizárólag úgy állíthatunk meg, ha ismerjük az azt alakító mögöttes tényezőket és azok szövevényes összefüggéseit. 


\section{Egészségmagatartási körkép - protektív és kocká- zati faktorok}

Az egészség olyan egyensúlyi állapot, melynek megőrzése a változó környezeti feltételekhez való adaptációs képesség függvénye. Az ehhez szükséges adaptációs kapacitás alapja a védőfaktorok megléte, melyek közül is kiemelkednek az ún. nem hagyományos védőfaktorok, melyek a pozitív személyiségjegyekben, érzelmekben és attitüdökben gyökereznek (Kovács és Pikó 2010a). Ezzel szemben „,a rizikómagatartás - vagy kockázati magatartás - olyan magatartásminták sorozata, amelyek intenzitásuk és/vagy tartósságuk következtében egészségi kockázatot hordoznak magukban" (Hüse-Huszti-Takács 2016:83). A négyévente ismétlődő, nemzetközi, hazánkra is kiterjedő, HBSC (Health Behaviour in School-Aged Children) elnevezésü kutatás magyarországi eredménye ijesztő képet fest a tizenévesek egészségmagatartásáról, de hasonló eredményeket hoznak az ESPAD (European School Survey Project on Alcohol and other Drugs) vizsgálatok - nem csak - magyar vonatkozásai is. Bár a serdülőkor a szerkipróbálás időszaka - és kísérleti jelleggel a lelki fejlődés része (Brassai és Pikó 2010) -, azonban a lelki egyensúly megbomlása, az életminőséget negatívan érintő változások morbiditáshoz vezethetnek és hozzájárulhatnak vezető halálokokhoz (szív- és érrendszeri, valamint daganatos megbetegedések), valamint mentális zavarokhoz is. A családi szokásrend és a barátok alkoholfogyasztása a két legmeghatározóbb motiváló erő ehhez (Pikó 2010b). A leggyakoribb egészségkockázati magatartás a dohányzás és az alkoholfogyasztás, melyekkel az első találkozás általában 14-15 éves kor körül történik (Brassai és Pikó 2010). A 2014-es HBSC-vizsgálatok szerint a 16 évesek kétharmada már legalább egy szál cigarettát elszívott, a serdülökorúak negyede pedig rendszeresen dohányzik (Arnold 2014a). E tekintetében nagyon fontos a barátok, de közülük is a legjobb barát példája, mely a legerösebb prediktornak bizonyult a kutatások alkalmával (Pikó 2010c). Alkoholfogyasztás tekintetében a 16 évesek 45\%-a legalább havi szinten lerészegedik (Arnold 2014b). Európai viszonylatban a 15 évesek 29\%-a heti gyakorisággal fogyaszt szeszesitalt, 30\%a pedig napi rendszerességgel dohányzik (Brassai és Pikó 2010). Az alacsonyabb társadalmi osztályba tartozók és akik szülei kevesebbet keresnek, azoknál gyakoribb a dohányzás, míg a drogfogyasztás a jobb anyagi helyzettel függ össze, a magasabb alkoholfogyasztás pedig adódhat a megengedő szülői nevelési gyakorlatból, valamint például helyi jellegből is, mint lakókörnyezeti kockázat (például bortermelő vidék). Vagyis a rizikómagatartások megjelenése nagyban függ egy térség kulturális hagyományaitól és gazdasági helyzetétől is (Balázs és mtsai 2010). Az alkoholfogyasztás nemek közötti eltérését mutatja, hogy a Magyar Ifjúságkutatás 2016-os eredményei alapján a lányok esetében több, mint $60 \%$ állította, hogy csak ritkán, vagy sohasem fogyaszt alkoholt, míg ez az arány a fiúk esetében kevesebb, mint 40\%.

Az együtt-ivás sokszor a serdülőkori rituálék részét képezi, a dohányzáshoz hasonlóan. Mondhatnánk azt is, hogy az ifjúsági szubkultúra része (Arnold 2014b). A kortárshatások fontosságát hangsúlyozva megállapítható, hogy azok a lányok, akiket társaik cigarettával vagy alkohollal kínálnak, háromszor olyan gyakran élnek ezekkel a szerekkel, mint akiket nem, míg a fiúk esetében ez az arány egy a kettőhöz (Brassai és Pikó 2005). Droghasználat tekintetében a hazai ESPAD-vizsgálatok kimutatták, 
hogy a 90-es évektől nő a droghasználat a serdülők körében. 1995-ben 5\%-uk, 2011ben már 20\%-uk nyilatkozott úgy, hogy legalább egyszer próbált már ki valamilyen drogot. A használt drogok közül a kannabisz (marihuána és hasis) 20\%-ban szerepelt (Arnold 2014c). Szintén ESPAD vizsgálatokban 30 európai ország adatait összesítve elmondható, hogy a 15 évesek 7,3\%-a már kipróbálta a marihuánát (Brassai és Pikó 2010). A drogokat főleg a bulikban használják, egyfajta lazítószerként. Kutatások kimutatták, hogy az egészségkockázati magatartások között erős korreláció van, a depresszió pedig esetenként kapcsolatban áll a dohányzással és a drogfogyasztással (Pikó 2010b). A szerfogyasztás ezen kívül más pszichés problémákkal, tanulási nehézségekkel és öngyilkossági gondolatokkal is társulhat (Brassai és Pikó 2010). A szexuális magatartással és a párkapcsolatokkal összefüggésben elmondható, hogy Magyarországon a tanulók egyharmada túl korán, 14 évesen, vagy fiatalabban szerzi meg első szexuális élményét, és a fiatalkori terhesség (10-14 év között), valamint a terhesség-megszakítások száma is óriási mértékü a nemzetközi viszonylatokhoz mérve: a teherbe esés 10-14 év kor között 1000-ből majdnem kettő (1.9) eset, melyek 60\%-a terhesség-megszakítással végződik. A 15-19 éves korosztályban a terhességmegszakítás aránya 41\%-os (Költő 2014).

$\mathrm{Az}$ egészségkockázati magatartás ellensúlyozására a két legfontosabb, főként egyéni választáson alapuló igen fontos protektív tényezö, azaz védőfaktor - a megfelelően funkcionáló társas kapcsolatokkal karöltve, melyek hozzájárulnak az egészség és jólét megőrzéséhez (Huszti 2014) - a rendszeres és intenzív testmozgás, és a tápanyagokban gazdag, kiegyensúlyozott táplálkozás. E két magatartásforma az egészségvédő magatartások közül a serdülök körében a leginkább vizsgált (Brassai és Pikó 2010). A HBSC 2014-es eredményi szerint a diákok alig fele fogyaszt rendszeresen reggelit, 29,4\%-a pedig soha. Az életkor növekedésével ez a tendencia nő. 10\%-uk még heti egyszer sem eszik gyümölcsöt, 32,6\%-uk viszont napi rendszerességgel, $18,2 \%$-uk pedig napi többször is. A zöldségfogyasztás hasonló arányú, és mindkettőnél megfigyelhető az életkor növekedésével járó fogyasztás-csökkenés. Az édességet tekintve a tanulók 30,3\%-a napi szinten eszik, szénsavas üdítőitalokat 26,3\% iszik minden nap, energiaitalokat pedig 8,9\%-uk (Németh 2014b). Pozitív adat, hogy a 1529 évesek háromnegyede fogyaszt fött ételt napi rendszerességgel (Magyar Ifjúságkutatás 2016). A közös étkezések tekintetében napi rendszerességgel a tanulók 14,3\%a étkezik közösen szüleivel, harmaduk azonban soha (Németh 2014b). Ez azonban fontos lenne, hiszen a közös vacsorázás a kutatások alapján egy fontos indikátora a családi együttlétnek (Hamvai és Pikó 2009). Vizsgálatok szerint a fiúkra inkább az állati eredetű zsírok és a húsalapú élelmiszerek fogyasztása, míg a lányokra a több édességfogyasztás mellett a gyakoribb zöldség-gyümölcs ill. tejtermék fogyasztása jellemző, valamint ők ritkábban esznek gyorsétteremből származó ételeket (Brassai és Pikó 2010). A reggelizéssel kapcsolatban továbbá megállapították, hogy annak kihagyása összefügg az alkohol- és drogfogyasztással, a dohányzással és a kevés testmozgással (Németh 2014a). Elmondható tehát, hogy a tudatos táplálkozás kialakítása - a hiányosságok kiküszöbölése mellett - serdülőkorban azért is lenne meghatározó, mert a táplálkozáskontroll a preventív magatartás-struktúra fontos részét képezi (Brassai és Pikó 2010).

Sportolás tekintetében a magyar vonatkozású HBSC-kutatások szerint a diákok csupán egyötöde mozog eleget, 28,3\%-uk szinte semmit, 30,1\%-uk pedig csupán keveset, 
pedig a rendszeres, legalább közepes intenzitású testmozgás többek között segít megelőzni a szív- és érrendszeri problémákat, csökkenti a szorongást és a depresszív tüneteket, valamint összességében javítja az életminőséget (Németh 2014a). A Magyar Ifjúságkutatás (2016) eredményei alapján a fiatalok 36\%-a sportol valamit a kötelező testnevelésórákon kívül, de 25\%-uk viszont mind hétköznap, mind hétvégén ,„csak úgy elvan" szabadidejében. A lányok helyzete rosszabb, mint a fiúké: nekik a harmadukra jellemző a nem megfelelö mértékü sportolás, míg a fiúknak az ötödére. Az életkor növekedésével a mozgás mennyisége is csökken (Németh 2014a). Pedig a sport minden életkorban az életminőség alapvető meghatározója és az élet minden területére hatással van - a rendszeresen sportoló fiatalok közül például kevesebben dohányoznak, szexuális életük biztonságosabb, valamint kedvezőbbek az étkezési szokásaik (Mikulán, Keresztes és Pikó 2010). A sport továbbá növeli az önbizalmat és segít megelözni a pszichoszomatikus tünetképzést, a depressziót, valamint az egészség önminősítésére is pozitív hatással van (Mikulán, Keresztes és Pikó 2010). Ezen kívül a sport jobb intellektuális teljesítményt, jobb közérzetet és nagyobb érzelmi stabilitást is eredményez, valamint a viselkedéskontrollt is fejleszti - a figyelem összpontosítását és az érzelmek szabályozását a feladatvégzés érdekében -, továbbá erősíti a jövőorientációt, hiszen a rizikómagatartások elutasításával egy jövőbeli egészséghaszon elérésére helyeződik át a figyelem (Brassai és Pikó 2010).

A sport megjelenhetne alternatívaként a túlzott mértékü képernyőhasználattal szemben is, hiszen a képernyős tevékenységek meghatározó szerepet töltenek be a fiatalok szabadidős tevékenységében, melyeket olyan új szabadidő-eltöltési formák erősítenek, mint a „telefonozás” és a facebookozás - ráadásul az okostelefonok elterjedésével ezek a tevékenységek már nem helyhez kötöttek (Magyar Ifjúságkutatás 2016). Televíziózás tekintetében a HBSC-vizsgálatok alapján a tanulók 54,6\%-a tölt 2 óránál többet tv-nézéssel, hétvégén pedig 80,4\%-uk; a 2-3 órás játék célú számítógép-használat a tanulók körében hétköznap 24,4\%, hétvégén 26,6\%. A több, mint kétórás internet-használat hétköznap 50,1\%-ban, hétvégén pedig 63,5\%-ban jelenik meg (Németh 2014a). Vizsgálatok szerint a serdülökori szerfogyasztásra hat a médiában megjelenő szerfogyasztás is, hiszen a mozifilmekben megjelenik az alkoholfogyasztás és a dohányzás, ami - ha pozitív kép alakul ki a serdülőkben azokkal szemben negatívan hat az egészségmagatartással kapcsolatos attitüdjeikre, döntéseikre (Pikó, Balázs és Page 2010). A dohányzás például a filmekben főként konfliktusos helyzetekben a stresszoldás eszközeként jelenik meg, az alkohol pedig a felnőttség szimbólumaként (Pikó, Balázs és Page 2010).

A társas támogatás, mint védőfaktor alapvetően járul hozzá a serdülők szubjektív jóllétéhez, élettel való megelégedettségükhöz, legyen szó akár a szülőkkel való kapcsolatról, akár a kortárs baráti kapcsolatokról. A szülői támogatás, a kapcsolat nyújtotta biztonságérzet, a problémák velük való megbeszélése olyan védőfaktor, mely a későbbi felnőttkorban is jelentős hatású (Hamvai és Pikó 2009). A családi kapcsolatrendszert tekintve kijelenthető, hogy az individualista társadalmak sajnos háttérbe szorítják a szociális készségeket, melyek hiányosságai a családi kapcsolatokban is megmutatkoznak, így téve diszfunkcionálissá egy jelentős védőfaktort. Ez azért fontos, mert az egészséges kötődésü családban felnőtt egyének életében kevesebb a depresszív és addiktív kórformák megjelenésének esélye, pontosan a hatékony társas támogatás következtében kialakuló jóllét-érzés magas foka miatt, szemben a hibásan 
müködő családokban tapasztalható elidegenedés-érzéssel, mely pedig megbetegedések kiinduló pontja lehet (Kovács és Pikó 2010b). A biztonságérzet megteremtésében (a kötődés kialakítása, mely serdülökorban is fontos), az értékek átadásában (például egészségtudatos vagy egészségkárosító magatartásformák mintája) és a világnézet alakításában egyaránt nagy szerepe van a származási családnak, és a család szerkezetében bekövetkező változások (például a szülők különköltözése) pedig a gyermekekre lelki, gazdasági és kapcsolati szinten egyaránt nagy hatást gyakorol (Kovács és Pikó 2010b). A család típusát tekintve elmondható, hogy az egyszülös és az újraalakult családi struktúra - és maga a válás is, mely a fiatalok mentális állapotára is kedvezőtlenül hat - szintén rizikófaktornak számít a serdülök szerfogyasztásával kapcsolatban. Ugyanez mondható el a felsőfokú végzettségü apák és háztartásbeli anyák esetében is. Ezzel szemben azonban az erős iskolai elköteleződés, a vallásosság gyakorlása és az istenhit protektív faktoroknak tekinthetők a szerfogyasztással kapcsolatban, melynek oka a pozitív közösségi hatásokban és a keresztényi értékek megélésében van (Brassai és Pikó 2005).

A vallással, mint protektív faktorral kapcsolatban kijelenthető, hogy a vallásos értékrend részét képező viselkedési szabályok alkalmazása a szocializáció része és kiemelt szerepe van a szerfogyasztás megelözésében (Kovács és Pikó 2010c). Megfigyelhető az a jelenség is, hogy a jelenkor vallásossága erősen sajátos, egyéni, szemben a klasszikus vallásgyakorlással, mely évszázadokig jellemezte a társadalmakat, s csak a tudományok fejlődésével, a fogyasztói társadalom kialakulásával és a globalizáció eredményeként megjelenő szekularizáció hatására szorult vissza, amikoris a vallás létjogosultsága megkérdőjeleződött (Kovács és Pikó 2010c). Az „elvallástalanodás” időszaka után azonban (amikor a történelmi egyházak veszítettek társadalmi szerepükből) új vallási mozgalmak, kisegyházak, szekták alakultak ki, és a spiritualitás fogalma pedig egyre népszerübb lett a vallásosság fogalma mellett (Kovács és Pikó 2010c). Így elmondhatjuk, hogy napjainkban egy új típusú, a spiritualitás új útjaira nyitó vallásosság van kialakulóban. Mivel a rítusok, a vallás iránti emberi igény alapvető, így nem szabad figyelmen kívül hagynunk annak protektív hatását, bármilyen mozgalomban, irányzatban jelenjen is meg, hiszen az egyéb, káros, ún. ,instant rítusok" (dohányzás, drogfogyasztás) ellen hat (Kovács és Pikó 2010c). A vallási aktivitás, a templomba járás, vallási rendezvényeken való részvétel szintén védelmet jelent a szerkipróbálásokkal szemben: a magukat vallásosnak tartó diákok kisebb eséllyel próbálják ki a marihuánát és a cigarettát, a nagy mértékben vallásosaknál pedig a nagyivás kockázata is kisebb (Kovács és Pikó 2010c).

A serdülők életében megjelenhetnek negatív életesemények is, melyek kedvezőtlenül befolyásolják egészségmagatartásukat. A szülők válása, munkahelyelvesztése, egy-egy betegség, a családon belüli konfliktusok mind olyan tényezők, melyek kedvezőtlenül befolyásolják a serdülők életminőségét, ráadásul minél fiatalabb korban érik őket ezek a hatások, annál nagyobb lelki teherként élik meg azokat (Hüse, Huszti és Takács 2016). Ez része a stresszterheltségnek, melyre a serdülök különféle válaszokat adhatnak. Leszögezhetjük azonban, hogy a negatív életesemények, a konfliktusok teljes hiánya a konfliktusmegoldó képesség fejlődését és az alkalmazkodást segítő karakterjegyek (kreativitás, önbecsülés, kompetencia, társas kapcsolatépítési készségek) fejlődését sem tenné lehetővé (Kovács és Pikó 2010a). Számos esetben megfigyelték kutatók, hogy bizonyos egyének az őket ért nehézségek, fizikai-lelki 
traumák ellenére is - azok feldolgozása után - lelkileg visszanyerték az egyensúlyukat, sőt, személyiségük fejlődött, illetve olyan esetekkel is találkoztak, amikor deviáns környezetben nevelkedő gyerekek később egészséges felnőttekké váltak (Pikó 2010a). Ez többnyire azért van így, mert a rezilienciával (lelki rugalmasság), mint személyiségjeggyel rendelkező tanulók - mely többek között magas önértékelést és élettel való elégedettséget, valamint diszpozíciós optimizmust foglal magában - többnyire aktívközelítő típusú coping-amódszert alkalmaznak, vagyis a problémák elől nem menekülnek, hanem szembenéznek azokkal (Pikó és Hamvai, 2012). Az egyensúlyi állapot helyreállítása érdekében a problémaközpontú és az érzelemközpontú coping-módszerek együttes alkalmazása az optimális, hiszen az előbbi túlsúlya káros szerfogyasztásra hajlamosíthat, míg az utóbbi túlzott mértékü preferálása betegségkeltő lehet (Pikó és Keresztes 2010). Számos tanulmány igazolta az optimizmus - „,mint a pozitív jövőbeli kimenetelre vonatkozó általános elvárás" (Pikó és Hamvai 2010:71) -és a fizikai állapot (mint egészségi-állapot változó), illetve az immunrendszer állapota közötti pozitív kapcsolatot, valamint kedvező hatását a coping-folyamatokra és azok kimenetelére is (Pikó és Hamvai 2010). Az élet értelmébe, kiszámíthatóságába és öszszefüggőségébe vetett hit, a derülátás, a teljesítménymotiváció és a jó időgazdálkodás szintén protektív tényezők, melyek negatívan befolyásolják az egészségkockázati magatartások gyakoriságát (Brassai és Pikó 2010). Kutatások szerint koherencia mutatkozik az élettel való elégedettség, valamint kompetens viselkedés és a pozitív életminőség, illetve az élet értelmébe vetett hit és a pozitív életminőség, továbbá az élet értelmébe vetett hit és az élettel való elégedettség között, amely protektív tényezőkkel a szerfogyasztás negatív kapcsolatot mutat (Brassai és Pikó 2010). A belsö kontrollal rendelkező egyének magatartásában kevésbé érvényesülnek a fogyasztói társadalom negatív hatásai, szemben - az egyre általánosabbá váló típussal - a külső kontrollal rendelkező emberekkel, akik könnyebben manipulálhatók (Pikó 2010a). Ezek a személyiséggel összefüggő, valamint a szociális jellemzők, mint például a családi kohézió vagy a társas támogatás az ún. nem hagyományos védőfaktorok közé sorolandók, melyekről elmondhatjuk, hogy az életminőségre, valamint a mentális egészségre és ezen keresztül a testi egészségre is erőteljes hatást gyakorolnak, a hagyományos, általában a primer prevencióban helyet kapó ún. hagyományos védőfaktorokkal együtt - mint például a az egészséges táplálkozás, a rendszeres testmozgás és a rizikómagatartásoktól való tartózkodás - kiemelkedően jelentősek (Kovács és Pikó 2010a).

A legnagyobb stresszt átélö fiataloknál megfigyelték, hogy már nem marad erejük küzdeni a stressz hatásaival, így gyakran maladaptív, egészségkárosító coping módszert választanak (Pikó és Hamvai 2012). Rózsa és munkatársai (2005) által a stresszel és megküzdéssel kapcsolatos kutatásában alkalmazott Életesemény skála mind a testi, mind a pszichológiai tüneteknek egyaránt fontos prediktorának bizonyult, míg a $M a$ gatartás és érzelmek skála a pszichológiai tünetképzésért volt felelős. A felnőtt lakosság mellett sajnos a serdülökre is igaz, hogy a krónikus stressz következtében gyakran folyamodnak alkoholhoz, mely szokás, ha állandósul és problémává válik, a későbbi életszakaszokban is az lesz. A szociális tanulás folyamata során ennek kialakulásában a barátok triggerelő, vagyis folyamatot elindító hatása és a szülők alkohollal kapcsolatos attitüdje és magatartása alapvetően meghatározó. Ilyen hatás például a liberális, megengedő szülői hozzáállás - a főleg magas társadalmi pozíciójú szülők esetében -, ami pozitív kapcsolatot mutat a magas alkoholfogyasztással (Balázs és Pikó 2013). A 
fenti tendenciát erősíti a posztkommunista országok negatív kulturális hatása is, mely szerint az alkoholfogyasztás olyan szociális motivációként jelenik meg - bizonyos mértékig - ami szükségszerü és kívánatos, mert megkönnyíti a kapcsolatteremtést, feszültségoldó hatású és egyfajta negatív problémamegoldó szerepe is van (Balázs és Pikó 2013). A stresszfaktorok ellensúlyozásaként a személynek olyan intrinzik célokat, egyéni aspirációkat kell kitüznünk magunk elé, mint például a sportbéli és tanulási motivációk, hiszen ezek a tényezők emelik a szubjektív jóllét és megelégedettség mértékét. Ehhez az eredményesség által megjelenő pozitív érzelmek túlsúlya és a negatív érzelmek viszonylagos hiánya is hozzájárul, személyiségünk kiteljesítése, belső céljaink megvalósítása által pedig értékesnek és értelmesnek érezhetjük az életünket (Margitics és Pauwlik 2008).

\section{Anyag és módszer}

Vizsgálatomban félig strukturált interjúk formájában tudakozódtam a serdülőkorúak egészségmagatartása, egészség-ismerete, életmódja, és az őket 14 éves koruk előtt ért negatív életesemények felöl. Interjús felmérésemben ${ }^{1} 10$ serdülőkorú, nyíregyházi fiatalt kérdeztem, 5 fiút és 5 lányt. Az életkoruk 16 és 18 év között mozgott (átlagéletkor 17 év), és úgy válogattam ki az alanyokat, hogy több társadalmi réteget képviseljenek, vagyis eltérő szocioökonómiai státusszal rendelkezzenek. Így pl. van olyan köztük, akinek egyik szülője orvos, míg egy másiknak irodai alkalmazott, vagy alkalmi munkás.

Kvalitatív kutatásként a vizsgálat sokkal inkább leíró jellegü, és a kis elemszám miatt inkább arra alkalmas, hogy elemzéskor mélységeiben tárja fel az egyes témaköröket. Az interjú személyesebb jellegü, mint a kérdőív, és a beszélgetés során számos olyan aspektusra is figyelni lehet, amire egy kérdőívben nem. Ilyen például a közlés hitelessége, az érzelmi reakciók és egyéb, non-verbális kommunikációs elemek. A barátságos légkör megteremtése is fontos az interjú folyamán, hiszen ez alapfeltétele a megnyílásnak, az őszinte válaszadásnak, valamint általa lehetővé válik az, hogy az interjúalanyok kifejthessék saját véleményüket egy-egy kérdéssel, témával kapcsolatban (Zolnai 2016). Ezt a folyamatot segítette a több területet is lefedő kérdéssor és a RÉS-skála (Redukált Életesemény Skála; Hüse, Huszti és Takács 2016) alkalmazása, mely a megélt negatív életeseményeket súlyosságuk szerint pontozva határozza meg a stresszterheltség fokát, és amely kutatási módszer kvantitatív jellegü. Így a két módszer ötvözése által hitelesebb és összetettebb, valamint összefüggőbb képet alkothattam az általam vizsgált témában interjúalanyaim körében. Elsö hipotézisem az volt, hogy - összhangban a hazai és nemzetközi kutatások eredményeivel - az általam vizsgált serdülőkorúak egészségmagatartásában is számos egészségkockázati tényező szerepel, így vizsgálatom tárgya részben annak megismerése volt, hogy ezek milyen mértékben vannak jelen náluk. Mivel a megélt negatív életesemények erős prediktoroknak bizonyulnak az egészségkockázati magatartásformák kialakulásában (Hüse, Huszti és Takács 2016), így ezek jelenlétét és hatásait is vizsgáltam az interjú-készítés során.

\footnotetext{
${ }^{1}$ a kérdéssort ld. a mellékletben
} 
Második hipotézisként feltételeztem, hogy a megélt negatív életesemények interjúalanyaim körében is jelentősen, negatívan hatottak az egészségmagatartásukra, vagyis azok megléte és esetleges halmozódása esetükben is pozitív korrelációt mutat az egésszégkockázati magatartások megjelenésével. Ennek igazolására az egészségmagatartás vizsgálata után összehasonlító elemzést végeztem. Előre megírt kérdéseim (30 db) egyfajta támpontot jelentettek csupán a kérdések témaköreit illetően, de ezeken belül a beszélgetések kötetlenek voltak, az alanyok szabadon kifejthették véleményüket, álláspontjukat az adott témával kapcsolatban. A kérdéseim irányultságában, valamint a vizsgálati eredményeim feldolgozásában és értelmezésében a HBSC-kutatás 2014-es magyar nemzeti jelentése, a Magyar Ifjúság 2016-os felmérése, valamint Pikó Bettina és munkatársainak kutatási eredményei adtak támpontot.

$\mathrm{Az}$ 1. számú táblázat foglalja össze interjúalanyok jellemzőit a főbb demográfiai változók mentén.

\begin{tabular}{|c|c|c|c|c|c|c|}
\hline & Nem & Kor & Iskolatipus & $\begin{array}{c}\text { Lakóhely } \\
\text { típusa }\end{array}$ & $\begin{array}{c}\text { Szülök iskolai } \\
\text { végzettsége } \\
\text { (anya/apa) }\end{array}$ & $\begin{array}{c}\text { Szülök foglalkozása } \\
\text { (anya/apa) }\end{array}$ \\
\hline Edina & nő & 16 & szakmunkásképző & falu & 8 általános & $\begin{array}{c}\text { közmunka, alkalmi } \\
\text { munka }\end{array}$ \\
\hline Anikó & nő & 17 & gimnázium & város & $\begin{array}{c}\text { felsőfok/ } \\
\text { szakmunkás }\end{array}$ & $\begin{array}{l}\text { alkalmazott/ } \\
\text { vállalkozó }\end{array}$ \\
\hline Petra & nő & 16 & szakközépiskola & város & középfok & alkalmazott \\
\hline Zsuzsi & nő & 17 & szakközépiskola & város & egyetem & $\begin{array}{l}\text { gyógyszerész/ } \\
\text { mérnök }\end{array}$ \\
\hline Bori & nő & 18 & szakközépiskola & város & $\begin{array}{c}\text { föiskola/ } \\
\text { szakmunkás }\end{array}$ & tanító/szakmunkás \\
\hline Botond & férfi & 16 & gimnázium & város & egyetem & közgazdász/orvos \\
\hline Gergő & férfi & 18 & gimnázium & város & egyetem & tanár/ügyvéd \\
\hline József & férfi & 17 & szakmunkásképző & város & $\begin{array}{c}\text { szakmunkás- } \\
\text { képző }\end{array}$ & varrónő/szakmunkás \\
\hline Marci & férfi & 17 & gimnázium & város & egyetem & tanár \\
\hline Zoltán & férfi & 18 & gimnázium & város & felsőfok/föiskola & $\begin{array}{l}\text { gyógyszertári asz- } \\
\text { szisztens/újságíró }\end{array}$ \\
\hline
\end{tabular}

1. táblázat. Interjúalanyaim és főbb demográfiai jellemzőik.

A kutatás során megkérdezett fiatalok átlagéletkora 17 év volt, a nemi arány megoszlása 50-50 \%-os. Egyikük faluban él, a többiek nagyvárosban. Iskolatípus szerint két tanuló szakmunkásképzőbe, három fő szakközépiskolába, és öt diák gimnáziumba jár. A szülők iskolai végzettsége a nyolc általánostól az egyetemig terjed, foglalkozásukat tekintve pedig az alkalmi munkástól az újságírón át az orvosig változatos foglalkozásokat találunk. 


\section{Eredmények és megbeszélés}

Az interjúkérdésekre adott válaszok elemzése által igen színes kép rajzolódott ki a különböző életutakkal kapcsolatban. Az eltérések alapvető okai az eltérö szocioökonómiai státuszban és a szülökkel való kapcsolat minöségében, az iskola típusában, valamint a baráti társaság jellegében keresendő, hiszen ezek a szocializációt meghatározó legfontosabb tényezők. A kapott válaszok feldolgozása elsőként egészségmagatartási szempontból történt, Szerhasználat és szórakozás, valamint Szexuális magatartás és párkapcsolatok fejezetcímek alatt, aztán következnek azok a fejezetek, melyekben a lehetséges védőfaktorok meglétét ill. hiányát, a társas kapcsolatok jellegét és a táplálkozási szokásokat elemeztem a kapott válaszok alapján alanyaim körében (Szülöi és kortárs-kapcsolatok; Sport és képernyöhasználat; Táplálkozás). Végül a Megélt negatív életesemények fejezete zárja a vizsgálatot, feltárva ezen események és az egészségmagatartási problémák közti összefüggést.

\section{Szerhasználat és szórakozás (dohányzási-, valamint alkohol- és drogfogyasztási szokások)}

A vizsgálatomban szereplő serdülők körében változó képet kaptam dohányzás és szerfogyasztás tekintetében. A lányok vonatkozásában Anikó, Petra és Zsuzsi hasonlóan pozitív egészségmagatartással jellemezhetők a dohányzás, valamint az alkohol- és drogfogyasztás szempontjából. Mindhárom lány igen ritkán jár el szórakozni (átlagosan 3-4 hetente egyszer, osztálytársaik társaságában, szórakozóhelyre, vagy szülinapi partykra), nem dohányoznak, soha nem próbáltak ki semmilyen drogot (bár Petrát és Zsuzsit már kínálták), és alkoholt is csak ritkán fogyasztanak és keveset: Anikó esetében 1 sör és egy feles jöhet szóba egy bulizós este alatt, Zsuzsinál pedig maximum 1-2 koktél. Petra szórakozóhelyen és házibulikon sohasem fogyaszt alkoholt, mert fél, hogy valamit kevernek az italába, csakis otthon, családi ünnepek alkalmával iszik, ilyenkor 1-2 üveg almabort.

Ugyanez a kedvező hozzáállás már nem mondható el Bori és Edina esetében. Bori, bár ritkán bulizik (havi-kéthavi egy alkalom), ilyenkor részegségig fogyaszt alkoholt és kb. egy fél doboz cigarettát is elszív - bár a hétköznapokban nem dohányzik. Drogot még nem próbált ki, bár már őt is kínálták, és bulikban jellemző, hogy idegen fiúkkal csókolózik - egy-egy estén akár többel is. Mindez azt mutatja, hogy a mindennapok elfojtott érzelmi reakciói, a családi veszekedések okozta intrapszichés feszültségek ventillálása ilyenkor történik meg esetében, kedvezőtlen, számos egészségkockázati magatartásforma társulásával. Edina igazi „,partyarc”, ahogyan ő nevezi magát: hetente 2 buliban is megfordul, és általában mindig részegségig iszik. Bár neki nincs sok pénze, mindig akad valaki, aki meghívja valamire. Így egy este végére 2-3 korsó sör és kb. 2-2,5 dl. tömény alkohol van a szervezetében. Ö rendszeresen dohányzik, még az iskolában is, titokban, a WC-ben. Néha droggal is kínálják, amit ö mindig készségesen elfogad. Talán ennek a hatása is, hogy már számos alkalommal volt egyéjszakás kapcsolata. 
A fiúk tekintetében ugyanilyen vegyes kép mutatható ki. Marci alkohollal, dohánnyal és droggal csak képeken találkozott, és bulizni sem jár soha. Zoltán igazi sportember, aki odafigyel egészségére és fizikai teljesítőképességének fenntartására. Csak ritkán jár bulikba (havi 1 alkalom), ilyenkor 1-2 sörön vagy 1 dl. tömény alkoholtól többet sohasem iszik és ezeket nem is keveri egymással. Ahogy mondja, neki elég ez is az ellazuláshoz. Társaságban is jól tudja magát érezni, ott kevésbé komoly, sokat nevet barátaival, ismeröseivel. Nem dohányzik és nem próbált még ki drogot - de már őt is kínálták kortársai. Botond a heti egy bulijában majdnem mindig berúg, sört, tömény alkoholt, bort, néha pezsgöt egyaránt fogyaszt. Nem dohányzik, de 1-2 füves cigit majdnem minden szórakozási alkalommal elszív. Gergő és József a fiúk között képviselik a nagyivókat: ők heti több, mint egyszer (általában kétszer) rúgnak be. Ök is vegyes összetételben fogyasztanak alkoholt, de ők rendszeres dohányzók is, valamint alkalmi füves cigi- és kannabisz fogyasztók.

\section{Szexuális magatartás és párkapcsolatok}

Interjúalanyaim szexuális magatartását és párkapcsolati elveit elemezve a fiúk tekintetében Zoltán önmagát hüséges típusnak vallja; egy szerelmi kapcsolata volt eddig. Neki fontos, hogy a szerelem és a szexualitás együtt járjon. Alkalmi kapcsolatokba nem bocsátkozik és jelenleg új barátnőt sem szeretne, mert szakítását még nem dolgozta fel. Védekezés tekintetében barátnőjével mindig óvszert használtak, ami talán a legbiztonságosabb védekezési módnak tekinthető mind a nem kívánt terhesség, mind a szexuális úton terjedő betegségekkel kapcsolatban egyaránt. Zoltán értékeit szülei nevelték belé: jól látszik esetében a megfelelő szülői kommunikáció és egymás megértése, ami fontos serdülőkorban. Problémái is meghallgatásra találnak szülei körében. Botondnak szintén volt már szexuális kapcsolata, három alkalommal, de ezek csak „egyéjszakás” kalandok voltak. Olyankor mindig óvszerrel védekezett. Párkapcsolata még nem volt. Esetében megmutatkozik a szülői odafigyelés hiánya, valamint az egyoldalú nevelés hatása. Gergő és József hasonló mentalitásúak: bár volt már barátnőjük, mégis mindketten egyaránt azt vallják, hogy nincs szükségük barátnőre, csakis laza kapcsolatokat akarnak. Szerintük a párkapcsolat nagyon időigényes és egy idő után a lányok követelőzők és parancsolgatók lesznek. Egyaránt arról számolt be mindkét fiú, hogy nem egyszer fordult már elő velük, hogy védekezés nélkül bonyolódtak szexuális aktusba, de egyáltalán nem félnek a kockázatoktól. Gergő szerint a lányok egy részét elég könnyen rá lehet venni a védekezés nélküli szexre. Marci még sohasem volt szerelmes, és sem párkapcsolata, sem szexuális kapcsolata nem volt még senkivel. Azt vallja, hogy jelenleg nem is vágyik ezekre, mert a tanulás leköti minden figyelmét.

A lányok közül Anikó Zoltánhoz hasonló típus: ő is a szerelmen alapuló párkapcsolatok híve. Neki is csak 1 szerelmi kapcsolata volt eddig, melyben szexuális tapasztalatokat is szerzett. Védekezés tekintetben óvszert használtak kapcsolata alatt mindvégig, mert teljes körü védelemre vágyott. A szülöi gondoskodásnak és figyelemnek itt is megvan a hatása: az érzelmileg érettebb viszonyulás a párkapcsolatokhoz. Borinak két kapcsolata volt már, ebből az első fiú iránt nem táplált túl mély érzelmeket, csak testi szinten vonzódott hozzá főleg, valamint ,jó volt vele együtt 
lenni”. Elmondása alapján az a kapcsolat inkább csak pótcselekvés volt az otthoni nehézségektől való menekülésre, és pont az érzelmek hiánya miatt hült ki hamar a kapcsolat. Egy idő után pedig olyannyira felszínessé vált, hogy Bori úgy döntött, hogy szakít a fiúval. A második kapcsolata már mélyebb volt, de nagy szerelemről itt sem beszélhetünk. Egyéjszakás kapcsolatai még nem voltak, de nem tartja kizártnak, hogy belemenne ilyenbe is, ha nagyon maga alatt lenne. Ez pedig elég gyakran jellemző rá. Védekezés tekintetében az első fiúval óvszert használtak, a másodiknál már fogamzásgátló gyógyszert. Bori esetében egyértelmüen érezhető a biztonságot nyújtó családi háttér hiánya.

Edina esetében a szerelmek inkább csak fellángolások voltak, melyeket a külső megjelenés váltott ki belőle. Ö amúgy is a hangsúlyt a külsőségekre helyezi, és ez megmutatkozik párválasztásában is. Neki már több egyéjszakás, vagy pár hétig tartó kapcsolata volt, hiszen gyakorta bulizik és általában ilyen alkalmakkor ismerkedik. A védekezésre azonban figyel, ugyanis nagyon fél a nemi úton terjedő betegségektől. Családi háttér-okokat vizsgálva itt a kevés és nem megfelelő szülői kommunikáció és a közte és szülei között lévő feszültség hatása érződik, mivel nála hiányoznak a pozitív nevelöi hatások és az egészséggel kapcsolatos ismeretátadás. Ez részben azzal magyarázható, hogy sokszor maguk a szülők sincsenek tisztában alapvető ismeretekkel, valamint a nevelés fontosságával.

Petra, a komoly sportoló még nem rendelkezik párkapcsolati és szexuális tapasztalatokkal. Most minden figyelmét a sportnak és a tanulásnak szenteli, ám megvallotta, hogy ha jönne a „nagy ő”, akkor szívesen lenne szerelmes. Addig mindenképpen várni akar szüzessége elvesztésével. Petrának szintén jó a kommunikációja szüleivel, főleg édesapjával, és ez a pozitív nevelő hatás érződik is hozzáállásán. Zsuzsi Petrához hasonló cipőben jár: neki volt már ugyan komoly kapcsolata, de még nem feküdt le senkivel. Az egyéjszakás kapcsolatoknak ő sem híve, sőt, elzárkózik előle. A jó szülői kommunikáció itt is megnyilvánul a mentalitásában.

\section{Szülői és kortárs-kapcsolatok}

Az interjúalanyok társas támogatottsága szintén eltérő. Gergő esetében az alacsony szülöi kontroll példája jelenik meg. Gergőt rendszeresen kérdezik szülei a tanulmányi jegyekkel kapcsolatban, de az ő esetében egyáltalán nincs korlátozva a szabadidő eltöltése, még a hétköznapokban sem. Gergő alapjában véve „nagy csavargó”, ahogyan ő nevezi saját magát, még hétköznap is sok időt tölt barátaival. Van úgy, hogy csak este 7-8 óra körül keveredik haza, ám ,éles eszének köszönhetően” hamar megtanulja másnapra, amit kell. A hétvégi bulik túlzott lazasága azonban érezteti esetében a túlzottan megengedő nevelési stílus negatív hatásait: sokszor részegedik le a nagyivások alkalmával, és a kábítószereket sem utasítja vissza. Gergő életfelfogása a kontrolláló szülöi szigor és kommunikáció hiánya miatt túl laza, és ez megmutatkozik alkalmi szexuális kapcsolataiban is. A tanuláson kívül ugyanis esetében szinte egyáltalán nincs kommunikáció és kapcsolódási pont a szülőkkel. Sokszor csak esténként, futólag találkoznak. A szülöi kontroll és monitorozás szinte csak tanulmányi eredményeinek figyelésére terjed ki, de Gergő sem gyakran fordul tanácsért szüleihez. Testvéri 
kapcsolatokat illetően neki öccse van, így inkább ő az, akinek foglalkoznia kell vele. Kortársak tekintetében elmondható, hogy igen kiterjedt kapcsolatrendszere van. Ezek azonban többnyire felszínes, sekélyes kapcsolatok, és inkább csak a bulizásokra és az iskolára vonatkoznak. Igazán mély barátsága csak 2-3 fiúval van, velük azonban mindent meg tud beszélni.

Botond esetében a szülöi szigor közepesnek mondható: a jó jegyek, sikeres vizsgák esetén a fiú eljárhat barátaival szórakozni, csavarogni, ám ez a hétköznapokra csak korlátozottan érvényes. Akkor a délutáni órákra már haza kell érnie és el kell kezdenie tanulni, ami azt jelenti, hogy iskolaidő után kb. két-három órája marad a barátaival lenni. Ezt az időt ő általában konditermi edzésekkel tölti, baráti társaságban. Hétvégén azonban bulizhat, és a részegségért sem szólnak neki. Gergőtől gyakrabban beszélget szüleivel, de ők is - Gergő szüleihez hasonlóan - föleg a tanulással kapcsolatban érdeklődnek. Az emberi dolgokról, érzelmekről, a társas kapcsolatairól sohasem beszélnek. Neki nincs testvére, így a testvéri támogatás lehetősége kiesik. Kortársakkal kapcsolatban sok barátja van, és sokukkal is tartja a kapcsolatot, de csak két olyan barátot említett, akikre tud támaszkodni bármiben, köztük az egyik Gergö.

Bori kommunikációja mindkét szülöjével hiányos. Édesapja alkoholizmusa miatt elérhetetlen, édesanyja pedig a családi problémák miatti magába fordulás miatt. Bátyja csak ritkán látogat haza, vele ilyen alkalmakkor órákat beszélget. Ilyenkor sok mindent átbeszélnek, és bátyja praktikus tanácsokkal szokta ellátni Borit. A családi problémák és veszekedések miatt Bori kicsit neurotikus, visszahúzódó személyiség lett, aki csak ritkán találkozik barátnőivel. Inkább otthon van és tanul, olvas, internetezik. Nyaranta diákmunkát vállal, hogy besegítsen édesanyjának a házi kasszába. Kortársak közül csak egy igaz barátnője van, de igazából a vele való kapcsolatát sem tartja olyan mélynek. Az iskolán kívül csak ritkán találkoznak, ilyenkor sétálnak, moziznak, vagy beülnek valahová beszélgetni.

Edina, kollégista lányként alig tartózkodik otthon, általában csak minden második héten megy haza. Ö sem otthon nem szeret lenni, sem szüleit nem szereti túlságosan. Kommunikációjuk csupán veszekedésekre korlátozódik, és csak esetleges. Két húga van, így velük nem igazán tud még beszélgetni semmiről az őt foglalkoztató kérdések köréből, őt viszont gyakran megkeresi a két lány, ha valami problémájuk akad. Kortársak tekintetében van egy barátnője, de felszínes a kapcsolata vele: együtt sportolnak, buliznak, de ebben ki is merül a kapcsolatuk.

Zsuzsi kapcsolata kiegyensúlyozott mind édesanyjával, mind édesapjával. Gyakran kirándulnak együtt a hegyekbe, és sokat is beszélgetnek. Náluk inkább az emberi dolgok állnak a beszélgetések középpontjában. Úgy érzi, mindenben támogatják és elfogadják szülei. Soha nem erőltetnek rá semmit, inkább arra törekednek, hogy megtalálja önmagát, és döntéseit tudatosan hozza meg. Barátnői közül csak eggyel van mélyebb kapcsolata. Zsuzsi gyakran fordul tanácsért nővéréhez is, egyrészt párkapcsolati kérdésekben, aki szívesen megosztja húgával tapasztalatait, de örömmel áll rendelkezésére más kérdésekben is.

Hasonló a helyzet Zoltánnál is, az ő szülei is mögötte állnak, csak ő édesapjával beszélget kevesebbet. Édesanyjával gyakran beszélgetnek, és szintén főleg nem anynyira a tanulás témakörében, mint inkább a mindennapok, az emberi értékek, problémák és a világ dolgaival kapcsolatban. Közös programjaik kevesebbek, mint Zsuzsiéknak, de ettől még harmonikusnak mondható a családi életük. Zoltán gyakran 
fordul tanácsért bátyjához, általában lányokkal kapcsolatban. Kikéri a véleményét azokról, akikkel ismerkedni szeretne, vagy akkor, ha pl. nem érti egy lány reakcióját valamilyen szituációban. Kevés vele egykorúval tartja a kapcsolatot, ő úgy gondolja, nincs igazi barátja, csak haverjai, akikkel alkalomadtán találkozik, szórakozik, de komolyabb kérdésekről, melyek őt érdeklik, nem tud velük beszélgetni.

Marci kapcsolata szüleivel igen merev és egyoldalú. Ök napi szinten kommunikálnak gyermekükkel, de ez csupán tanulmányi elömenetelének elömozdítására vonatkozik. Érzelmi dolgairól, esetleges problémáiról, benső nehézségeiről, kérdéseiről sohasem érdeklődnek, és mivel öccse van, így vele még nem tud komolyabb dolgokról beszélgetni. Marcit magát sem nagyon foglalkoztatja jelenleg más, csak a tanulás, annyira azonosulni tudott szülei szemléletével. Kortárskapcsolatai kizárólag az iskolára korlátozódnak. Élete szinte kizárólag a tanulás körül forog, az iskola után soha sehová nem mehet, csakis egyenest haza. Szülei meg vannak győződve arról, hogy nagyon jó tanulmányi eredményt csakis nagyon sok és koncentrált tanulás útján lehet elérni - amire azért Gergő is ellenpélda. Marci így sok mindenből kimarad, nincs sok barátja, de nem is hiányoznak neki az együtt „lógások”, hiszen ezt a kemény, követelmény- és teljesítményalapú rendszert szokta meg kisiskolás kora óta. Kérdésként felmerül azonban nála, hogy a kimaradt élmények és társas interakciók, szereppróbálgatások hiányának visszahatása mikor és milyen mértékben fog jelentkezni. Ez sokszor sajnos akkor jelentkezik, mikor a túl szigorúan fogott serdülő elkerül föiskolára, egyetemre, ahol teljes mértékben eltünik a szülöi kontroll. Ilyenkor általában a viselkedés átcsap a másik oldalra, és féktelen tobzódásban, életélvezetben, valamint káros egészségmagatartásban nyilvánul meg.

József kapcsolata jónak mondható szüleivel, nincs közöttük konfliktus, ám kommunikációjuk sekélyes, felszínes, pusztán a mindennapi kérdéseket érintik. Náluk a tanulás, mint téma, teljesen kimarad. Testvérét ritkán látja, és nem szokott vele beszélgetni akkor sem túl sokat, amikor hazalátogat. Baráti kapcsolatai a konditermi edzésekre és bulizásokra korlátozódnak, de szavait értelmezve nem mélyek ezek a kapcsolatok. Józsefet azonban ez egyáltalán nem zavarja, mert az edzésen és szórakozáson kívül egyébként sem igazán érdekli semmi más.

Anikó kapcsolata édesanyjával kiemelkedő, édesapjával elfogadható. Anyukájával nagyon sokat és rendszeresen, napi szinten beszélgetnek. Ö az, akire támaszkodhat nehézségei idején, ő vigasztalta szakításakor is. Testvére már külön él tőlük, de az Interneten keresztül rendszeresen tartja vele is a kapcsolatot, és kb. kéthetente találkoznak is. Sok mindent meg szokott vele beszélni, de igazán mélyen édesanyja számára tud megnyílni. Barátnője egy van, vele azonban csak általános dolgokról szokott beszélgetni, úgymint tanulás, öltözködés, táplálkozás, fiúk.

Petra kapcsolata édesapjával szorosabb, mint édesanyjáéval, akivel jóval kevesebbet beszélget, és aki inkább a tanulásban segíti. Apukája, egyfajta „másodedzőként”, a lánya mellett áll és mindenben támogatja a sikeres sport érdekében. Petra sokat tanul, így a sport mellett nem jut túl sok ideje barátokra, mégis kiegyensúlyozottnak érzi az életét. 


\section{Sport és képernyőhasználat}

A sportolás tekintetében interjúalanyaim körében szinte mindenki sportol valamit, más-más intenzitással. A manapság oly népszerü „kondizást”, vagyis edzőtermi súlyzózást 10-ből 4-en jelölték meg, mint rendszeresen végzett, iskolán kívüli sporttevékenységet. Ezek közül Botond és Gergő az izmosabb, szebb külső elérése miatt edzenek. A délutáni edzések egyúttal baráti összejöveteleknek is számítanak nekik, hiszen számos évfolyamtársukkal is ott találkoznak, akikkel együtt edzenek. Ezt a tevékenységet általában heti 4 alkalommal végzik. Bori számára az intrapszichés feszültségek levezetésére szolgál az edzés, úgy érzi, ezzel megkönnyebbül valamelyest. József számára az átlagostól valami egészen mást jelent a kondizás: ő a versenyszerü testépítés bủvkörében él már két esztendeje. Egyre inkább a testépítésnek rendel alá mindent, és egy ideje illegális szteroidokat (izomtömeg-növelö hormonkészítményeket) is használ. Abban a hitben él, hogy a lányok a nagyon izmos fiúkhoz vonzódnak jobban, ezért próbál megfelelni ennek az általa vélt ideálnak. Az ő sportolása tehát már nem az egészség megőrzéséről és fejlesztéséről szól, hanem az egészség rombolásáról. Petra kirívó a sportolási szokásokat illetően az interjúalanyok között: ö profi sportoló szeretne lenni, súlyemelő edzésekre jár. Illegális szerekhez azonban nem szeretne nyúlni, sem most, sem a későbbiekben. Úgy tartja, hogy az emberben olyan tartalékerőforrások vannak, melyek újabb és újabb sikerek elérését, jobbnál jobb egyéni rekordok felállítását teszik lehetővé. Számos, sportoláshoz kapcsolódó személyiségfejlesztő témájú sportpszichológiai könyvet olvasott már, melyek ismereteit a gyakorlatban is kipróbálta edzései és regenerálódása során. Látható tehát, hogy bár Petra igen elkötelezett a sporteredmények iránt, mégis megörizte egészséges gondolkodását és esze ágában sincs tiltott teljesítményfokozókhoz nyúlni.

Edina választott sporttevékenysége az aerobic, de ő nem azért jár heti háromszor órákra, mert annyira tetszene neki az a típusú mozgás, hanem mert csinosan akar kinézni, hogy minél több fiúnak nyerje el a tetszését. Beszélgetésünk során kiderült, hogy mozgásos tevékenységét egyfajta kényszerként éli meg, és szívesebben ülne a TV elött. Ha azonban nem szeretjük azt a mozgásos tevékenységet, melyet üzünk, annak következménye előbb-utóbb a motiváció csökkenése, az edzések egyre gyakoribb kihagyása, majd végleges abbahagyása lesz.

Zsuzsi és Zoltán a futást választották sportjuknak. Míg Zsuzsi csak nemrég kezdte el a rendszeres, tanórán kívüli testmozgást, addig Zoltán óvodás kora óta fut: hosszútáv- és tájfutó versenyekre is jár. Zsuzsi motivációja a csinosodás, a fogyás, Zoltán számára pedig egyfajta életstílus, ami relaxációt, nyugalmat hoz a mindennapjaiba. Mint már említettem, Zoltán gondolkodó típus, és elmondása szerint szeret egyedül lenni és „,csak futni” az erdőben. Ilyenkor tisztábbnak érzi gondolatait, és sokszor így talál megoldást kérdéses életszituációira, döntéshelyzeteire is.

A megkérdezettek közül két tanuló, Marci és Anikó sajnos egyáltalán nem sportol semmit iskolán kívül. Ez megmutatkozik abban is, hogy egyedül ők tartják az iskolai testnevelésórákat nehéznek és fárasztónak, míg a többiek csak közepes erősségünek értékelték. Marci szülei számára egyáltalán nem fontos a sport, a mozgás, ők kizárólag fiúk értelem-béli fejlődését tartják szem előtt, így nem is ösztönzik őt sportolásra. A mozgás egyébként az ő életükből is teljesen hiányzik. Anikó esetében szintén elmarad 
a sport, ő inkább szereti szobája csendjét, és előnyben részesíti a tanulást, az olvasást. A tanulás azonban sokkal jobban megy, ha valamilyen sporttevékenység váltja fel időnként: az egyik tevékenységben ugyanis ki lehet pihenni a másikat. Mindkét tevékenység feltöltő hatású, ha az ellenkezőben lemerültünk, elfáradtunk.

Televíziózás és nem tanulási célú számitógép- és Internet-használat tekintetében is vegyes képet kaptam alanyaim szokásait illetően: Marci, Anikó, Zoltán és Petra televíziót szinte sohasem néznek, és számítógépet is csak hétvégén, 1-3 órára, Internetezés céljából használnak, érdeklődési körüknek megfelelö témában. Zsuzsi hétvégén megnéz egy-két müsort, számítógépet Internetezésre használ, hétköznap 1-1 órán át, hétvégén 2-3 órát. Bori mindennap átlagosan 1 órát internetezik és 1 órát néz televíziót. József és Edina a leginkább tv-nézők: napi 2-4 órát is szánnak erre, hétvégén pedig esetenként még többet. Számítógépes játékok és Internet-használat tekintetében ez napi 56 óra is lehet náluk. Gergő és Botond a televíziót ritkábban, a számítógépet pedig gyakrabban használják: televízió nézésére napi 1 órát, internetezésre és számítógépes játékokra 3-5 órát fordítanak, és inkább hétvégén teszik ezt. Kutatások eredményei alapján érdemes megjegyeznünk, hogy a tévénézési szokásokat nagyban befolyásolja a szülöi mintaadás, valamint a szociokulturális környezet is: a veszélyes lakókörnyezet (rendezetlen családi kapcsolatrendszer) növeli az ezzel töltött időt (Németh 2014a).

\section{Táplálkozás}

Interjúalanyaim többségére elmondható, hogy hiába sportol a többségük, mégsem táplálkoznak megfelelően. A testépítést végző fiúk (Botond, Gergő és József) ugyan figyelnek a napi tápanyag-bevitelre - magazinok ajánlásával kiszámítják a testtömegükhöz ajánlott fehérje-, szénhidrát- és zsírbevitelt -, s közülük József talán túlzásba is viszi az ezzel való foglalkozást, de a bulizások és nagyivások alkalmával ők is háttérbe szorítják táplálkozási elveiket. Egy-egy buli alkalmával több étkezés is kimarad, valamint a másnaposság hatására az étvágy csökkenése figyelhető meg. A családdal való együtt-étkezéseket tekintve Botond csak hétvégén, Gergő csak a nagyszülök meglátogatásakor, József azonban soha nem étkezik együtt a szüleivel.

A vizsgálatomban szereplő lányok közül szinte mindenki figyel az étkezésére, kivéve Anikót, aki nem is sportol semmit. Ö elégedett magával, és nem is diétázik. Általában nem hagy ki fóétkezést, és napi kétszer együtt eszik szüleivel. Petra a fiúkhoz hasonlóan nagyon odafigyel az étkezéseire, de neki kell is, hiszen nagyon komoly sporttevékenységet végez. A fiúkkal ellentétben azonban ő csak nagyon ritkán és igen kismértékben fogyaszt alkoholt, így ennek negatív hatásai nála nem jöhetnek szóba. Szüleivel napi egyszer, általában vacsora alkalmával étkezik együtt. A többi lány (Zsuzsi, Edina és Bori) azonban nagyon figyel az étkezésére, próbálnak folyton diétázni, mert nagyon elégedetlenek testképükkel. Úgy érzik, hogy tudják hol a határ, kivéve Edinát, aki már többször is bajba került túlzó diétázása miatt: volt, hogy az iskolából a mentő vitte el. Tisztában is van a kockázatokkal, de szerinte ,a szépség megéri a szenvedést". Félö, hogy az anorexia nervosa (az evészavarok egy formája; koplalás) kialakulása is elkezdődött nála, mivel folyton kövérnek látja magát. Serdü- 
lőkorban ez egyre gyakoribb jelenség az evészavarok egy másik jellegzetes megjelenési formájával, a bulimia nervosa-val együtt, ami pedig túlevésben mutatkozik meg. Az egészségtelen divatirányzatokhoz alkalmazkodni kívánó serdülők gyakran negatívan ítélik meg tápláltsági állapotukat: a lányok általában fogyni, a fiúk izmosodni akarnak (Németh 2014c). Ennek eléréséért a lányok sokszor nem tudományos forrásból származó, drasztikus diéta-módszerekhez, a fiúk illegális izomtömegnövelö-készítményekhez folyamodnak. Sokszor azonban a serdülök nem veszik figyelembe azt, hogy az újságban látott példakép fotóján megjelenő kinézet csupán a verseny napján létezik, több hónapos felkészülési és diétázási szezon után! Alapvető ismeretekkel nincsenek tehát tisztában, melyek hiánya téves döntésekhez és egészségügyi problémákhoz vezethet náluk. Azonban ,,mind a kedvezötlen testképpel, mind az egészségtelen testtömeg-csökkentö magatartásokkal szemben védenek a jó családi és kortárskapcsolatok, a társas támogatás, az iskolához való kötödés, a kritikus gondolkodás képessége és a nemi szereppel való elégedettség” (Németh 2014:161c).

\section{Megélt negatív életesemények}

A negatív életesemények olyan egészségkockázati prediktorok, melyekre fontos odafigyelni egy-egy serdülö esetében, hiszen megfelelő szintü és mértékü beavatkozás szükségességére hívhatja fel a figyelmet a szakemberek részéröl. Dolgozatomban a RÉS (Redukált Életesemény Skála; Hüse, Huszti és Takács 2016) elnevezésű mérőeszköz kérdéseit alkalmaztam interjúalanyaimra, melyekkel kiegészítettem az interjú során kapott adatokat. A RÉS alapja a Holmes-Rahe-féle SRRS (Social Readjusment Rating Scale) életesemény-skála, mely egy 43 itemet tartalmazó lista, ahol a szerzők 11 és 100 pont között pontoznak egy-egy megélt, negatív életeseményt, annak megfelelően, hogy az pszichésen mennyire megterhelő az egyén számára. 150 pontig alacsony, 300 pontig közepes mértékü, és e felett pedig erős stresszt átélt egyénről beszélhetünk (Hüse, Huszti és Takács 2016). A „Magyar ifjúság 2012” kutatásban a szerzők ennek a skálának egy 37 itemből álló változatából válogattak ki 8-at és ezt kiegészítették további 4 olyan életeseménnyel, melyek az eredeti skálában nem szerepeltek. A felmérés kutatói az eseményekhez nem rendeltek pontszám-értékeket, csak azt vizsgálták, hogy az esemény előfordult-e. A vizsgálat fókuszában az állt, hogy az adott személy 14 éves koráig megélte-e a listában szereplő negatív életesemény valamelyikét, esetleg többet is. Nyíregyházi kutatók ezekhez az életeseményekhez újra pontszámokat rendeltek, az eredetei Holmes-Rahe-féle skála és egy vegyes összetételü, 23 tagból álló, szakértői csoport becslése által, és így született meg a Redukált Életesemény Skála (RÉS). Ezek az életesemények és a hozzájuk rendelt pontok a következők: elvesztette a munkahelyét a szülöje vagy a nevelöszülöje (46 pont); elváltak a szülei (90 pont); durva veszekedések voltak a szülei között (47 pont); súlyos anyagi veszteség érte a családjukat (45 pont); szakitás baráttal, barátnővel (53 pont); súlyos betegség (ön vagy a családjának valamelyik tagja) (57 pont); rendszeresen lerészegedett a szülöje vagy a nevelöszülöje (75 pont); meghalt az édesapja vagy az édesanyja (100 pont); közvetlen környezetében (családjában, baráti körében) öngyil- 
kossági kísérlet az elmúlt 3 évben (76 pont); rendszeresen megverték vagy bántalmazták Önt a szülei, nevelöszülei (90 pont); abortusz (ön vagy a partnere) (100 pont); halállal végzödö öngyilkossági kísérlet a közvetlen környezetében (családjában, baráti körében) (90 pont).

Interjúalanyaim negatív életeseményeinek vizsgálata alapján arra a megállapításra jutottam, hogy a szóban forgó 12 negatív életesemény a vizsgálat alanyok körében is igen jelentős prediktoroknak számítanak az egészségkockázati magatartás szempontjából. Négy tanuló esetében (Marci, Gergő, Petra és Botond) a felsoroltak közül egy életesemény sem történt meg 14 éves korukig. Gergő és Botond esetében a szülők magas társadalmi presztízse, Marci és Petra esetében pedig a tanuláshoz (és sportoláshoz) szükséges tökéletes háttér megteremtése áll részben e jelenség mögött, mint védőfaktorok. Persze betegség, vagy egyéb, negatív esemény bekövetkezte az ő életükben is előfordulhatna, de erről nem számoltak be. Aggasztó a helyzet azonban Edina, József és Bori esetében, akiknél a leggyakoribbak az átélt negatív életesemények. Edina esetében 7 esemény, Józsefnél 4, Borinál pedig 5 esemény következett be. Edina életében 14 éves koráig szülö munkahelyelvesztése, durva szülöi veszekedések, súlyos anyagi veszteség, baráttal való szakitás, súlyos betegség családban, szüló rendszeres lerészegedése és az utóbbi 3 évben a környezetében elöfordult öngyilkossági kisérlet mind jelen voltak. A 896 maximális pontszámból 399 pontot kapott, vagyis a stressz jelentős mértékben része az életének. Ez megmutatkozik a fentiekben bemutatott tanulási- barátkozási- szabadidö-eltöltési szokásaiban és nem túl egészségközpontú gondolkodásában egyaránt. József esetében szülö munkahely-elvesztése, durva szülöi veszekedések, családot ért súlyos anyagi veszteség, súlyos betegség a családban eseményei fordultak elő. A 896 pontból 195 „negatív” pontot szerzett. Életmódjában, felfogásában szintén érződnek az átélt dolgok kedvezőtlen hatásai. Borinál szülö munkahelyi elvesztése, durva szülöi veszekedések, családot ért súlyos anyagi veszteség, szakitás baráttal és szülö rendszeres lerészegedése történt meg. Az ő pontszáma 266 pont. Figyelemre méltó, hogy mindhárom fiatal esetében jelen voltak szülökkel kapcsolatos problémák, ami kedvezőtlenül befolyásolja a családi kapcsolatrendszert. Ez Edina esetéhez hasonlóan a másik két fiatalnál is érezteti hatását személyes életük területein. A többiek esetében személyes kötődésủ negatív életesemény „csupán” egy-egy fordult elö, és kisebb fajsúllyal, mint az imént tárgyalt esetekben. Zoltán és Anikó életében a szülő munkahely-elvesztése (46 pont), Zsuzsi esetében pedig egy családon belüli súlyos betegség (57 pont) volt jelen. A megélt negatív életesemények számát, súlyosságát és az egészségmagatartási problémák jelenlétét, halmozódását szemlélteti a 2. táblázat. 


\begin{tabular}{|c|c|c|c|}
\hline & RÉS-pontszámok & $\begin{array}{c}\text { Egészségmagatartási } \\
\text { problémák }\end{array}$ & $\begin{array}{c}\text { Megfigyelt vé- } \\
\text { döfaktorok }\end{array}$ \\
\hline Edina (16) & 399 & $\begin{array}{l}\text { dohányzás, alkohol- } \\
\text { és drogfogyasztás, in- } \\
\text { adekvát szexuális } \\
\text { magatartás }\end{array}$ & - \\
\hline Bori (18) & 266 & $\begin{array}{l}\text { időnkénti nagyivások } \\
\text { és dohányzás }\end{array}$ & $\begin{array}{l}\text { sport, tanulási } \\
\text { motiváció }\end{array}$ \\
\hline József (17) & 195 & $\begin{array}{l}\text { dohányzás, rendszeres } \\
\text { nagyivások és drogfo- } \\
\text { gyasztás, inadekvát } \\
\text { szexuális magatartás }\end{array}$ & - \\
\hline Zsuzsi (17) & 57 & - & $\begin{array}{l}\text { sport, tanulási } \\
\text { motiváció, tá- } \\
\text { mogató család }\end{array}$ \\
\hline Anikó (17) & 46 & - & $\begin{array}{l}\text { tanulási moti- } \\
\text { váció, támo- } \\
\text { gató család }\end{array}$ \\
\hline Zoltán (18) & 46 & - & $\begin{array}{l}\text { sport, tanulási } \\
\text { motiváció, tá- } \\
\text { mogató család }\end{array}$ \\
\hline Gergő (18) & 0 & $\begin{array}{l}\text { dohányzás, rendszeres } \\
\text { nagyivások, drogfo- } \\
\text { gyasztás és inadekvát } \\
\text { szexuális magatartás }\end{array}$ & $\begin{array}{l}\text { sport, tanulási } \\
\text { motiváció }\end{array}$ \\
\hline Botond (16) & 0 & $\begin{array}{l}\text { rendszeres nagyivások } \\
\text { és drogfogyasztás }\end{array}$ & $\begin{array}{l}\text { sport, tanulási } \\
\text { motiváció }\end{array}$ \\
\hline Petra (16) & 0 & - & $\begin{array}{l}\text { sport, tanulási } \\
\text { motiváció }\end{array}$ \\
\hline Marci (17) & 0 & - & $\begin{array}{l}\text { tanulási } \\
\text { motiváció }\end{array}$ \\
\hline
\end{tabular}

2. táblázat. A megélt negatív életesemények és az egészségmagatartási problémák közötti kapcsolat az interjúalanyoknál.

\section{Összegzés}

Amint azt az országos nagymintás kutatások adataiból (HBSC, ESPAD, Magyar Ifjúság) láthattuk, a mai magyar társadalom serdülőinek egészségmagatartása igen nagymértékben fejlesztésre szorul. Vizsgálatomban arra a következtetésre jutottam, hogy az alacsony szocioökonómiai státusz, a serdülők rossz, vagy egyoldalú kapcsolata a szülökkel, az alacsony szülői kontroll, valamint a negatív irányba befolyásoló kortárs kapcsolatok mind hozzájárulnak a fiatalok egészségkockázati viselkedéséhez. Mint 
láthattuk, ezek elkerüléséhez önmagában a jó szociokulturális háttér sem mindig elegendö, ha a szülök figyelme nem terjed ki a serdülök érzelmi életével való törődésre, a szülö-gyerek közti bizalmas kapcsolat kialakítására. Az egészséges szemléletü, némiképp teljesítmény-alapú sportolás és a tanulási motiváció szintén egészségvédő hatású, ám fontos, hogy ezek a tevékenységek ne szorítsák ki a kortárs-kapcsolatokat. Egyre inkább elmondható, hogy a szülői egészségnevelés hiányának pótlását a jövőben a formális nevelés lesz kénytelen markánsabban magára vállalni és hatásos egészségfejlesztő programokkal megpróbálni az iskoláskorúak egészségkockázati magatartását mérsékelni. Az egészségért történő egyéni felelösségvállalás erősítése (mind a serdülö, mind a felnőtt populáció körében) és az egészséges, aktív életmód kialakítására tett társadalmi erőfeszítés szintén kívánatos lenne hiszen „az egészségvédő magatartás nem egyszerüen az egészségkockázati magatartásformák hiánya, hanem egészségtudatos döntés eredménye" (Brassai és Pikó 2010:65). Az összefogás, a társadalmi párbeszéd kialakítása azonban nehéz egy olyan országban, ahol a felnőtt lakosságot bizalmatlanság, általános elégedetlenség és egymástól való elidegenedés jellemzi (Csite 2009). Ennek hatása a serdülők körében is egyre inkább érezhető: a kapcsolatok elsivárosodása és az online kommunikáció túlsúlya figyelhető meg, melyek ellehetetlenítik a tartalmas, bizalmon alapuló kortárs közösségek létrejöttét és fennmaradását. Ez azért is nagy probléma, mivel iskoláskorban lenne a legnagyobb szükség arra a jól müködő társas kapcsolatrendszerre, ami támogatása által (social support) hidat képezhet másokhoz, így téve lehetővé a makrotársadalmi integrációt és a jóllét (well-being) kialakítását egyaránt (Huszti 2014). Fontosnak tartom tehát a témával kapcsolatos további kutatásokat, hiszen eredményeik kijelölhetik a szociálpolitika azon irányát, mely egészségfejlesztő programjaival a felnövekvő nemzedékek pozitív, egészségközpontú gondolkodását és felelősségteljes döntéseken alapuló, önmagával és természeti-társadalmi környezetével egyaránt összhangban lévő életmódjának megteremtését segítik elö.

\section{Felhasznált irodalom}

1. Arnold Petra (2014a): Dohányzási szokások. In: Németh Ágnes, Költő András [szerk.], Egészség és egészségmagatartás iskoláskorban. Az iskoláskorú gyermekek egészségmagatartása elnevezésü, az Egészségügyi Világszervezettel együttmüködésben megvalósuló nemzetközi kutatás 2014. évi felméréséről készült nemzeti jelentés. 47-57.

2. Arnold Petra (2014b): Alkoholfogyasztási szokások. In: Németh Ágnes, Költő András [szerk.], Egészség és egészségmagatartás iskoláskorban. Az iskoláskorú gyermekek egészségmagatartása elnevezésü, az Egészségügyi Világszervezettel együttmüködésben megvalósuló nemzetközi kutatás 2014. évi felméréséről készült nemzeti jelentés. 58-72.

3. Arnold Petra (2014c): Drogfogyasztási szokások. In: Németh Ágnes, Költő András [szerk.], Egészség és egészségmagatartás iskoláskorban. Az iskoláskorú gyermekek egészségmagatartása elnevezésű, az Egészségügyi Világszervezettel 
együttmüködésben megvalósuló nemzetközi kutatás 2014. évi felméréséről készült nemzeti jelentés.73-86.

4. Balázs Máté Ádám, Pikó Bettina (2013): Serdülőkori alkoholfogyasztást befolyásoló tényezők: a szociális háló és a barátok szerepe. Mentálhigiéné és Pszichoszomatika (14), 1: 25-44. DOI: 10.1556/Mental.14.2013.1.2

5. Balázs Máté Ádám, Pikó Bettina, Dékány Katalin, Pluhár Zsuzsanna (2010): Lakóhely és a lakókörnyezet: Kockázat vagy védelem? In: Pikó Bettina [szerk.], Védőfaktorok nyomában. A káros szenvedélyek megelőzése és egészségfejlesztés serdülőkorban. Budapest, L'Harmattan. 159-186.

6. Brassai László, Pikó Bettina (2005): Szociodemográfiai, egyéni és viselkedési változók hatása a serdülőkori szerfogyasztásra. Mentálhigiéné és Pszichoszomatika (6), 2: 77-93.

7. Brassai László, Pikó Bettina (2010): Protektív pszichológiai jellemzők szerepe a serdülők egészséggel kapcsolatos magatartásában. In: Pikó Bettina [szerk.], Védőfaktorok nyomában. A káros szenvedélyek megelőzése és egészségfejlesztés serdülökorban. Budapest, L'Harmattan. 55-70.

8. Huszti Éva (2014): Társas kapcsolatok Nyíregyházán. In: Hüse L., Takács P. [szerk.], Acta Medicinae et Sociologica. (5), 12-13: 143-164. DOI:10.19055/ams.2014.5/12-13/9

9. Hüse Lajos, Huszti Éva, Takács Péter (2016): A gyermekvédelem peremén. Negatív életesemények hatása a kamaszok és fiatalok egszségkárosító magatartására. Metszetek, (5), 4: 80-108. DOI 10.18392/METSZ/2016/4/5

10. Kovács Eszter, Pikó Bettina (2010a): Az ún. nem hagyományos kockázati és egészségvédő faktorok jelentősége, In: Pikó Bettina [szerk.], Védőfaktorok nyomában. A káros szenvedélyek megelözése és egészségfejlesztés serdülőkorban. Budapest, L'Harmattan. 23-38.

11. Kovács Eszter, Pikó Bettina (2010b): A család egészségvédő hatása a serdülők körében. In: Pikó Bettina [szerk.], Védőfaktorok nyomában. A káros szenvedélyek megelőzése és egészségfejlesztés serdülőkorban. Budapest, L'Harmattan. 131-142.

12. Kovács Eszter, Pikó Bettina (2010c): A vallásosság mint a serdülők szerfogyasztásának védőfaktora, In: Pikó Bettina [szerk.], Védőfaktorok nyomában. A káros szenvedélyek megelőzése és egészségfejlesztés serdülőkorban. Budapest, L'Harmattan. 143-158.

13. Költő András (2014): Szexuális magatartás és romantikus tapasztalatok. In: Németh Ágnes, Költő András [szerk.], Egészség és egészségmagatartás iskoláskorban. Az iskoláskorú gyermekek egészségmagatartása elnevezésü, az Egészségügyi Világszervezettel együttmüködésben megvalósuló nemzetközi kutatás 2014. évi felméréséről készült nemzeti jelentés. 121-130.

14. Költő András, Zsiros Emese (2013): Serdülők lelki egészsége - A magyar iskoláskorú fiatalok mentális egészségének alakulása 2002 és 2010 között. Educatio. 2: 187-200.

15. Margitics Ferenc (2009): A szülői mesterség iskolája. Budapest, Scolar Kiadó.

16. Margitics Ferenc, Pauwlik Zsuzsa (2008): Személyes törekvések kapcsolata a szubjektív jólléttel föiskolai hallgatóknál. Mentálhigiéné és Pszichoszomatika (9), 1: 1-33. DOI: 10.1556/Mentál.9.2008.1.1 
17. Mikulán Rita, Keresztes Noémi, Pikó Bernadett (2010): A sport mint védőfaktor: fizikai aktivitás, egészség, káros szenvedélyek. In: Pikó Bernadett [szerk.], Védőfaktorok nyomában. A káros szenvedélyek megelőzése és egészségfejlesztés serdülőkorban. Budapest, L’Harmattan. 115-130.

18. Németh Ágnes (2014a): Fizikai aktivitás és képernyőhasználat. In: Németh Ágnes, Költő András [szerk.], Egészség és egészségmagatartás iskoláskorban. Az iskoláskorú gyermekek egészségmagatartása elnevezésü, az Egészségügyi Világszervezettel együttmüködésben megvalósuló nemzetközi kutatás 2014. évi felméréséről készült nemzeti jelentés. 31-45.

19. Németh Ágnes (2014b): Táplálkozási szokások és fogápolás. In: Németh Ágnes, Költő András [szerk.], Egészség és egészségmagatartás iskoláskorban. Az iskoláskorú gyermekek egészségmagatartása elnevezésü, az Egészségügyi Világszervezettel együttmüködésben megvalósuló nemzetközi kutatás 2014. évi felméréséről készült nemzeti jelentés.18-30.

20. Németh Ágnes (2014c): Tápláltsági állapot, testkép és testtömeg-szabályozás. In: Németh Ágnes, Költő András [szerk.], Egészség és egészségmagatartás iskoláskorban. Az iskoláskorú gyermekek egészségmagatartása elnevezésü, az Egészségügyi Világszervezettel együttmüködésben megvalósuló nemzetközi kutatás 2014. évi felméréséről készült nemzeti jelentés. 160-171.

21. Pikó Bettina (2010a): Védőfaktorok nyomában: Pozitív fordulat a magatartáskutatásokban? In: Pikó Bettina [szerk.], Védőfaktorok nyomában. A káros szenvedélyek megelőzése és egészségfejlesztés serdülőkorban. Budapest, L'Harmattan. 11-22.

22. Pikó Bettina (2010b): Szegedi ifjúságkutatás 2000, 2008: Káros szenvedélyek és a depressziós tünetegyüttes előfordulása serdülők körében. In: Pikó Bettina [szerk.], Védőfaktorok nyomában. A káros szenvedélyek megelőzése és egészségfejlesztés serdülőkorban. Budapest, L'Harmattan. 39-54.

23. Pikó Bettina (2010c): Közösségi hatóképesség és más társas befolyás szerepe a serdülők dohányzásában és alkoholfogyasztásában. In: Pikó Bettina [szerk.], Védőfaktorok nyomában. A káros szenvedélyek megelőzése és egészségfejlesztés serdülőkorban. Budapest, L'Harmattan. 87-102.

24. Pikó Bettina (2010d): Védőfaktoroktól az egészségtudatosságig: A kognitív szempontú egészségfejlesztés és addiktológiai prevenció, In: Pikó Bettina [szerk.], Védőfaktorok nyomában. A káros szenvedélyek megelőzése és egészségfejlesztés serdülőkorban. Budapest, L'Harmattan. 203-207.

25. Pikó Bettina, Balázs Máté Ádám, Page, R. M. (2010): A médiatudatosság jelentősége az addiktológiai prevencióban. In: Pikó Bettina [szerk.], Védőfaktorok nyomában. A káros szenvedélyek megelőzése és egészségfejlesztés serdülőkorban. Budapest, L'Harmattan. 187-198.

26. Pikó Bettina, Hamvai Csaba (2010): Az optimizmus mint a serdülők szerfogyasztásának és pszichikai egészségének védőfaktora. In: Pikó Bettina [szerk.], Védőfaktorok nyomában. A káros szenvedélyek megelőzése és egészségfejlesztés serdülőkorban. Budapest, L'Harmattan. 71-86.

27. Pikó Bettina, Hamvai Csaba (2012): Stressz, coping és reziliencia korai serdülökorban. Iskolakultúra (22), 9: 24-33. 
28. Pikó Bettina, Keresztes Noémi (2010): Serdülők egészségmagatartása két szociális coping-mechanizmus tükrében, In: Pikó Bettina [szerk.], Védőfaktorok nyomában. A káros szenvedélyek megelőzése és egészségfejlesztés serdülőkorban. Budapest, L'Harmattan. 103-114.

29. Rózsa Sándor, Kő Natasa, Csoboth Csilla, Purebl György, Beöthy-Molnár András, Szebik Imre, Berghammer Rita, Réthelyi János, Skrabski Árpád, Kopp Mária (2005): Stressz és megküzdés - A Rahe-féle Rövidített Stressz és Megküzdés Kérdőívvel szerzett hazai eredmények ismertetése. Mentálhigiéné és Pszichoszomatika. (6), 4: 275-294.

30. Zolnai Erika (2016): Kvalitatív módszerek alkalmazási lehetőségei a szakdolgozat megírása során, In: R. Fedor Anita, Huszti Éva [szerk.), Kutatásmódszertani kézikönyv. Debreceni Egyetemi Kiadó. 26-53.

\section{Internetes hivatkozások}

1. Csite András (2009): Boldogtalan kapitalizmus? A mai magyarországi társadalom értékpreferenciáinak néhány jellemzője. Közjó és Kapitalizmus Intézet, Mühelytanulmány. 10: 1-43. http://hetfa.hu/ wp-content/ uploads/ 2010/09/ Csite.Ertek2008.pdf (Utoljára látogatva: 2018.03.23)

2. Hamvai Csaba, Pikó Bettina (2009): Serdülők szubjektív jóllétét meghatározó társas tényezők a családban és az iskolában. Új Pedagógiai Szemle, (4). (online változat: http://ofi.hu/tudastar/hamvai-csaba-piko; Utoljára látogatva: 2018. 03. 23.)

3. Magyar Ifjúságkutatás 2016. Az ifjúságkutatás első eredményei. Ezek a mai magyar fiatalok! http:/www.ujnemzedek.hu/sites/default/files/magyar_ifjusag_2016_a4_web.pdf (Utoljára látogatva: 2018.04. 05.)

\section{Melléklet}

\section{Interjú-kérdések}

1. Milyen típusú középiskolába jársz?

2. Hány éves vagy?

3. Mi a legkedveltebb szabadidő-eltöltési formád?

4. Sportolsz-e rendszeresen? (heti minimum 2 alkalom, az iskolai testnevelésórák mellett)

5. Ha igen, mit sportolsz?

6. Ha sportolsz, kivel sportolsz?

7. Milyen nehézségünek ítéled meg az iskolai testnevelésórákat egy 1-től 10-ig terjedő skálán, ahol a 10-es a nagyon nehezet jelenti?

8. Gyakran beszélgetsz szüleiddel?

9. Kihez fordulsz leginkább tanácsért, ha problémád van?

10. Gyakran étkezik-e együtt nálatok a család?

11. Hány órát töltesz televíziónézéssel hétköznaponként, illetve hétvégén?

12. Hány órát fordítasz számítógép-használatra nem tanulási célból (internetezés, játékok) hétköznaponként, illetve hétvégenként?

13. Szoktál bulikba, partykba járni? Ha igen, milyen gyakran? 
14. Milyen gyakran fogyasztasz alkoholt?

15. Ha fogyasztasz alkoholt, azt milyen környezetben teszed leginkább?

16. Mennyi alkoholt fogyasztasz alkalmanként?

17. Dohányzol-e? Ha igen, milyen gyakorisággal?

18. Próbáltál-e már ki valaha bármilyen drogot?

19. Ha igen, mit?

20. Használsz-e rendszeresen valamilyen drogot jelenleg?

21. Volt-e már szexuális kapcsolatod?

22. Élsz-e rendszeres szexuális életet?

23. Ha igen, védekezel-e valamilyen formában?

24. Hogyan tartod leginkább a kapcsolatot barátaiddal, ismeröseiddel?

25. Facebook-ismerőseid közül hány emberrel tartod a kapcsolatot legalább heti rendszerességgel (az osztálytársakat leszámítva)?

26. Könnyen kötsz ismeretségeket?

27. Hogyan határoznád meg tudásodat az egészséges életvitellel kapcsolatban? (táplálkozás, testmozgás, mentális-lelki egészség).

28. Hogyan határoznád meg tudásodat a szexuális úton terjedő betegségek és a szenvedélybetegségek területén?

29. Igényt tartanál-e az egészségfejlesztéssel kapcsolatos többlet órákra, foglalkozásokra? Ha igen, milyen formában?

30. Mit tervezel a középiskolai tanulmányaid befejezése után? 